\title{
Self-care of elderly people after the diagnosis of acquired immunodeficiency syndrome
}

Idosos cuidando de si após o diagnóstico de síndrome da imunodeficiência adquirida

Ancianos cuidando de sí después del diagnóstico de síndrome de inmunodeficiencia adquirida

\section{Graciela Machado de Araujo', Marinês Tambara Leite", Leila Mariza Hildebrandt", Cinthia Cristina Oliveski", Margrid Beuter"II}

I Secretaria Municipal de Saúde. Palmeira das Missões, Rio Grande do Sul, Brazil.

"Universidade Federal de Santa Maria. Palmeira das Missões, Rio Grande do Sul, Brazil.

I"' Universidade Federal de Santa Maria, Health Sciences Center. Santa Maria, Rio Grande do Sul, Brazil.

How to mention this article:

Araujo GM, Leite MT, Hildebrandt LM, Oliveski CC, Beuter M. Self-care of elderly people after diagnosis of acquired immunodeficiency syndrome. Rev Bras Enferm [Internet]. 2018;71(suppl 2):793-800.

[Thematic Issue: Health of the Elderly] DOI: http://dx.doi.org/10.1590/0034-7167-2017-0248

Submission: 04-11-2017_Approval: 08-06-2017

\begin{abstract}
Objective: to characterize the seropositive elderly for the Human Immunodeficiency Virus and Acquired Immunodeficiency Syndrome (HIV/AIDS) in their socio-demographic aspects; to understand how the elderly take care of themselves from the diagnosis of HIV/AIDS. Method: Qualitative, descriptive, exploratory research conducted at a Voluntary Counseling and Testing Center with 10 elderly people receiving treatment for HIV/AIDS. The data were analyzed according to the content analysis. Results: Data show the elderly people's lack of knowledge about HIV/AIDS transmission, the experience of being elderly and having HIV/AIDS, caring for oneself and life after diagnosis of HIV/AIDS in their daily lives. Final considerations: The diagnosis of HIV/AIDS seropositivity in the elderly generates a blend of feelings and fears that lead to food changes, adherence to treatment and the renunciation of daily and social habits, manifested as ways of self-care.
\end{abstract}

Descriptors: Elderly; HIV; Nursing; Self-Care; Geriatrics.

\section{RESUMO}

Objetivo: caracterizar os idosos soropositivos para o vírus da Imunodeficiência Humana e Síndrome da Imunodeficiência Adquirida (HIV/Aids) em seus aspectos sociodemográficos; compreender como os idosos cuidam de si a partir do diagnóstico de HIV/Aids. Método: Pesquisa de abordagem qualitativa, descritiva, exploratória realizada em um Centro de Testagem e Aconselhamento, com 10 idosos em tratamento para HIV/Aids. Os dados foram analisados de acordo com a análise de conteúdo. Resultados: Os dados mostram o (des)conhecimento por parte dos idosos acerca da transmissão do HIV/Aids, a vivência da condição de ser idoso e ter HIV/Aids, o cuidado de si e como é a vida após o diagnóstico de HIV/Aids em seu cotidiano. Considerações finais: O diagnóstico da soropositividade para HIV/Aids nos idosos gera uma mistura de sentimentos e receios que repercutem em mudanças alimentares, na adesão ao tratamento e na renúncia de hábitos cotidianos e sociais, manifestados como formas de cuidar de si.

Descritores: Idoso; HIV; Enfermagem; Autocuidado; Geriatria.

\section{RESUMEN}

Objetivo: caracterizar a los ancianos seropositivos para el virus de la Inmunodeficiencia Humana y el Síndrome de Inmunodeficiencia Adquirida (HIV/SIDA) en sus aspectos sociodemográficos; comprender cómo los ancianos cuidan de sí a partir del diagnóstico de HIV/SIDA. Método: Investigación de abordaje cualitativo, descriptivo, exploratorio realizado en un Centro de Pruebas y Asesoramiento, con 10 ancianos en tratamiento para HIV/SIDA. Los datos fueron analizados de acuerdo con el análisis de contenido. Resultados: Los datos muestran el (falta de) conocimiento por parte de los ancianos acerca de la transmisión del HIV/SIDA, la vivencia de la condición de ser anciano y tener HIV/SIDA, el cuidado de sí y cómo es la vida después del diagnóstico de HIV/SIDA en su cotidiano. Consideraciones finales: El diagnóstico de la seropositividad para HIV/ 
SIDA en los ancianos genera una mezcla de sentimientos y temores que repercuten en cambios alimentarios, en la adhesión al tratamiento y en la renuncia de hábitos cotidianos y sociales, manifestados como formas de cuidar de sí.

Descriptores: Anciano; HIV; Enfermería; Autocuidado; Geriatria.

CORRESPONDING AUTHORＭarinês Tambara LeiteＥ-mail: tambaraleite@yahoo.com.br

\section{INTRODUCTION}

Aging is a stage of human development characterized by biological, social, cultural, spiritual and psychological changes. The preservation of good habits favors aging with quality of life. Still, in old age, family relationships and religiosity constitute important sources of support ${ }^{(1)}$.

Chronologically, for the World Health Organization (WHO), the elderly are every person aged 65 years and over, for individuals living in developed countries and 60 years or older for the inhabitants of developing countries, as is the case of Brazil . It should be noted that chronological age is not always a concise marker to establish the changes that come with aging, since old age is characterized by being multidimensional ${ }^{(2)}$.

In Brazil, the age pyramid has been changing in recent decades. This is because the population that is increasing the most is the elderly, with growth rates expected at around $4 \%$ per year between 2012 and 2022. This population increased from 14.2 million in 2000 to 19.6 million, in 2010, reaching 41.5 million in 2030 and 73.5 million in $2060^{(3)}$.

The aging of the Brazilian population is due, in part, to a reduction in the fertility rate, a decrease in mortality due to infectious diseases and an increase in longevity. This age transformation is associated with the behavioral changes of people in old age. An example of this is the active participation of the elderly in group meetings, artistic activities, religious, congresses, among other spaces of interaction. These behaviors, together with technological development in the field of health, especially in the field of pharmacological medicine, which has therapies such as hormone replacement and drugs that improve sexual performance, enable the elderly to rediscover different experiences, among them is sexuality and $\operatorname{sex}^{(4)}$.

In this direction, sexuality is understood as an integral element of the life of any individual, in its different stages. However, when it comes to sexuality in old age this theme is still little explored and discussed in the various health care settings. This is evident from a literature review using the descriptors AIDS and elderly and sexuality in which 23 manuscripts were located. Of these, 11 had a specific approach regarding the subject under study, six were literature reviews and another six had been produced from secondary data. The studies that deal with this issue point out that the greater exposure of the elderly to HIV/AIDS may be associated with factors such as the delay in the implementation of prevention policies aimed at this age group; the invisibility of sex in old age; the demystification of sexuality in the elderly coupled with the expansion of access to medicines for erectile disorders and the participation of the elderly in cohabitation groups; and the low adherence to the use of male condoms by the elderly ${ }^{(5-6)}$. This may reflect the care given to the elderly, especially those with the Human Immunodeficiency Virus (HIV) or the diagnosis of Acquired Immunodeficiency Syndrome (AIDS) ${ }^{(5)}$.

Although some biological and psychological factors may interfere with their performance, it is identified that the elderly continue to exercise their sexuality, including sexual intercourse. However, still in relation to the elderly population, there are many myths and beliefs that sex and sexuality do not exist in old age. As a result of this stereotyped view, issues on safe sex are usually ignored. Thus, unsafe sexual practices, associated with the demystification of sex in this age group make elderly people more likely to Sexually Transmitted Infections (STIs), including HIV/AIDS ${ }^{(6)}$.

On the evolution of HIV/AIDS in the elderly, it is observed that there is a progressive increase of this morbidity in this age group over the years. This is because, while in the first phase of the AIDS epidemic (1980/1997), 2,706 cases were reported in Brazil in individuals over 60 years of age, in a second period between 1998 and 2014, the number of cases in the elderly increased to 20,565 , of which $12,670(61.61 \%)$ were men and 7,895 (38.39\%) were women ${ }^{(7)}$.

In this scenario, health professionals should be aware of measures to prevent sexually transmitted diseases and/or acquired immunodeficiency virus, since elderly people are also exposed. In addition, it is necessary to adopt research and identification actions for the elderly infected with HIV/AIDS.

When considering the adverse and potentiating context of negative manifestations in the health of elderly individuals, as in the case living with HIV/AIDS, self-care becomes an important way for the maintenance of the well-being of this social group. Self-care is understood as having a wide network of meanings and involves questions of self-knowledge, perception and attention to one's own health and the environment in which one is inserted, contemplating interpersonal relationships ${ }^{(8)}$.

The situation of being elderly, being experiencing a chronic infectious contagious disease, associated with the sexuality aspects, was constituted in a panorama of study interest, since they are nursing areas and other health professionals. In addition, it is considered that the compilation of knowledge about the sexuality and desires of elderly people is still a taboo or is transposed by prejudices and myths.

Also, studies on this theme may contribute to the planning of interventions, in the sense of socialization and sharing of information, both for elderly people and their families, as well as for health professionals. Considering the aspects described, the question was: How do elderly people take care of themselves from the diagnosis of HIV/AIDS?

\section{OBJECTIVE}

To characterize the HIV/AIDS seropositive elderly people in their sociodemographic aspects; To understand how the 
elderly people take care of themselves from the diagnosis of HIV/AIDS.

\section{METHOD}

\section{Ethical aspects}

This study followed the recommendations of Resolution $466 / 2012$ of the National Health Council(9). The same received favorable opinion for its execution of the Research Ethics Committee of the Universidade Federal de Santa Maria.

\section{Type of study}

Research with a qualitative, exploratory and descriptive approach.

\section{Study scenario}

The research was developed together with the HIV/AIDS Voluntary Counseling and Testing Center (VCT) of a municipality in the northwestern region of Rio Grande do Sul State. It should be noted that the VCT is a public health service that carries out diagnostic and prevention actions of sexually transmitted diseases. Tests are carried out on HIV, syphilis and hepatitis B and C in accordance with the norms established by the Ministry of Health and with products registered with the Brazilian Health Surveillance Agency (ANVISA). All care is confidential and the individual who carries out the test is accompanied by a team of health professionals who guides you about the final result of the exam. If the result is positive, the VCT directs people to treatment. In addition, it provides guidance and clarification on the disease, treatment and ways of preventing complications. It also provides prevention supplies such as male and female condoms for everyone, lubricating gels and harm reduction kits for people who use drugs ${ }^{(10)}$.

\section{Data source}

The VCT, site of the research, is a reference for 26 surrounding municipalities, and it is currently registered 12 seropositive elderly. Of these, 10 were interviewed and two did not integrate into the study, because they did not access the service during the data collection period. The inclusion criteria in the study were: being 60 years or older; positive serology for HIV/AIDS; being on antiretroviral treatment and acquiring medication in VCT; having the cognitive conditions to respond to the interview.

\section{Collection and data organization}

In relation to cognition and with the purpose of selecting elderly individuals with cognitive conditions to respond to the interview, the Mini-Mental State Examination (MMSE) was applied previously, which has five dimensions: spatial-temporal orientation, memory, attention, naming and obedience, and copying of a complex design ${ }^{(11-12)}$. It is worth mentioning that all elderly people contacted scored higher than 23 in the MMSE, which indicated an absence of cognitive deficit.

In order to produce data, the researcher remained in the VCT and approached the elderly when they accessed the service to follow up and/or withdraw medications, inviting them to participate in the research. When checking that the user approached met the inclusion criteria and accepted to participate in the interview, clarifications were made about the objectives and how the data collection would take place. Once they agreed to participate in the research, both the researcher and the participant signed the Free and Clarified Consent Term. The interviews were conducted in a private room, within the health service itself.

After obtaining the MMSE result, the participant was invited to continue the interview, for which a semi-structured tool containing closed questions regarding socio-demographic data was used. It also contained open-ended questions used to mark the interview: Tell me, How is having HIV/AIDS like? Has there been a change in your life from the diagnosis of HIV/AIDS? Tell me, how did you start taking care of yourself from the time you were diagnosed with HIV/AIDS? The interview was recorded in digital media with digital voice recorder, later transcribed in full. Data production occurred in the period from March to June 2016.

\section{Data analysis}

To analyze the data we followed the steps of content analysis, which consisted of pre-analysis, material exploration and analysis and coding process ${ }^{(13)}$. In this way, the material was organized and the documents to be analyzed were chosen. In the case of the interviews, these were duly transcribed and their meeting constituted the corpus of the research. The material was prepared by "editing" the transcribed interviews, considering the research objectives. Subsequently, there was material exploration and coding, where the raw data were processed in an organized way and grouped into categorical units ${ }^{(13)}$.

Thus, initially, we proceeded to characterize the participants, sequentially, by convergence of ideas. Three categories of analysis were developed. A report on '(Lack of) knowledge of the elderly about HIV/AIDS transmission'; the second was nominated as 'Experiencing the condition of being old and having HIV/AIDS and the self-care'; and the third presents aspects related to 'Life after the diagnosis of HIV/AIDS: facing the everyday'. In order to preserve the identity of the interviewees we used the vowel $\mathrm{E}$ followed by corresponding numbering (E1, E2, E3,...).

\section{RESULTS}

\section{Characterization of participants}

A total of 10 users aged 60 years and over from the HIV/ AIDS Testing Center participated in the study, seven of whom were female and three were male (7) from the Catholic religion. The age of the interviewees ranged from 60 to 77 years, with the majority (7), in the age group between 60 and 70 years. In relation to the marital situation, six were widowed, three married and one divorced. As for the occupation, all interviewees were retired and received from one to three minimum monthly salaries. They were independent in functional capacity, they themselves took their antiretroviral medication monthly in the health service. The displacement of the elderly to the VCT occurred by means of own vehicle, of collective transport and some were taken by the transportation service provided by the municipal health department of the municipality of origin. The time of diagnosis of the disease 
and treatment ranged from nine months to 13 years, with an average of six years.

Regarding the educational level, all interviewees reported incomplete elementary education. This data may be one of the factors that contributed to exposure and, consequently, to HIV/AIDS illness, since these individuals had less knowledge to process information on prevention and health care.

With regard to leisure activities, the elderly mentioned dances, parties, walks and playing musical tools as preferred activities, which benefits quality of life, encourages socialization, development and personal independence. Among the elderly, two reported that from the diagnosis of HIV/AIDS, they stopped doing leisure activities.

From the reading and re-reading of the content coming from the statements of the interviewed elderly, three categorical units were constructed that are presented next.

\section{(Lack of) knowledge of elderly people about the transmis- sion of HIV/AIDS}

AIDS is a morbidity that can affect individuals of different age groups, social levels, gender and level of education. Among the conditions that contribute to the exposure and risk of contamination is the knowledge about the disease, because the understanding about the forms of contagion constitutes a fundamental part for the person to be protected, using the protective devices available.

When questioned about their knowledge about HIV/AIDS, before being diagnosed, some of the elderly responded that they had no knowledge.

$$
\text { Nothing, I had no knowledge, I hadn't any. (E4) }
$$

No, never dear, I saw sometimes talking about it, but I didn't even know what it was. (E10)

However, others reported having a little knowledge of the disease, but the speeches show superficial and distorted information.

Oh I knew, I knew and when I found out I thought I was going to die, when I knew what I had I just went crazy [...] I thought it killed [...] I thought like this: I'm going out on the street and I'll throw myself under a car. (E2)

On the form of contamination, the results of the present study evidenced sex as the only source of contagion:

Yes, through sex, I was single, I was alone, and then there was a guy who infected me. (E6)

It is contradictory that elderly people report that they know practically nothing about HIV/AIDS before being diagnosed and declare that they know that the contamination occurred through sexual intercourse. This shows that the dialogue about sexuality between professionals and the elderly seems to have occurred only after diagnosis of HIV/AIDS infection. Moreover, perhaps the idea of the desexualization of the elderly and the invisibility of the problem by the nursing professionals and between the elderly public itself, contribute to this issue being approached in the daily life of the work only when there is the process of illness.

\section{Experiencing the condition of being old and having HIV/ AIDS and self-care}

Not telling anyone about their diagnosis or restricting knowledge about their condition of having HIV/AIDS to few people from their daily life is common among the elderly interviewed. When they chose to tell someone, they generally choose a member closer to the family.

I'd rather anyone knowing about my case. (E1)

From my family, only my niece who knows. (E3)

Keeping their health condition confidential is a fairly common practice among respondents. The exercise of this behavior, which is usually associated with the fear of withdrawing people from their family and social life, may, at some point, trigger negative repercussions on the health of the elderly.

Regarding the feelings related to having the HIV/AIDS diagnosis revealed, expressions such as: fear, shame, embarrassment and guilt emerged throughout the interviews.

I feel very, very, very embarrassed. (E2)

Sometimes I feel embarrassed, but now I'm used to it. Thinking about me being an old woman like that, with this stuff. I feel embarrassed with people sometimes... (E6)

Guilt is a feeling that comes most often from the recognition of being partly responsible for having HIV/AIDS. The embarrassment and fear of social responses and being discovered as seropositive by people, with whom they interact, are constant in the lives of elderly people interviewed.

At the beginning of the epidemic, the HIV/AIDS diagnosis was faced as a death sentence, the patient was "sentenced". However, the technological advance in antiretroviral treatment gave another vision of the future to seropositive individuals. However, when experienced by the elderly, it can still be frightening and signify the anticipation of death.

Self-care can be expressed in many ways, through attitudes that range from the renunciation of old habits to the adoption of new ways of life. Respondents stated that they take care of themselves, through new healthier eating practices and adherence to treatment.

I try to take the medicine always at the right time, to eat better, and I don't drink anymore. (E1)

I take the medicine, I eat well and when I have sex is protected, with condom. But I take care of myself on the food I have, but it seems like the stomach is very sensitive, it doesn't accept fatty food so much, so I eat more greens, lean meat, but the rest is normal. (E2)

Still, in the search for self-care, old habits are left aside and new practices are adopted. However, there seem to be changes about the sexual intercourse. 
Only this sex stuff, no, I don't wanna know about it, because men don't agree to use condoms. (E1)

Since smoking, cigarette these things if people are smoking I leave, at home I demand that they don't smoke indoors. And I take the medicine correctly. I get some girlfriends from time to time, but it's not always, but it's obvious that I'm careful, I'm warned, that it doesn't happen, it's happened to me, but I hope it doesn't happen to others. (E8)

So that the human beings can take care of themselves, they need to know what is best for themselves or at least to know how to mitigate what is harmful for them. The moment you learn to recognize what harms you, you have the possibility to avoid it or minimize it, making life more affable. It is understood, then, that the decision of self-care demands the individual's attitudes committed to their health condition, aiming at alternatives to obtain personal satisfaction and quality of life.

\section{Life after HIV/AIDS diagnosis: coping with everyday life}

AIDS, as well as being a chronic disease, it is a social phenomenon that has the power to impact the moral and ethical principles on issues related to sexuality and usually leads one to rethink their attitude, their daily lives and to change their behavior. When it comes to a disease like AIDS, for its stigmatizing characteristics often people change their lifestyle and relationships.

In this sense, it was identified that the elderly modified their lifestyle and their behavior after the HIV/AIDS diagnosis. This triggered changes in the social and health dimensions, causing isolation and reduction of contact with people.

Leisure my dear, I liked going out, I used to go dancing with old people, and now after that I have never gone there anymore. (E3)

I have a prejudice with myself, I don't go to elderly people places, I don't like interacting, sometimes I go to lunch, and I go back to my house. (E10)

Interruptions of activities, previously routine, may be justified by the embarrassment generated by the diagnosis of an infectious disease, fear that its condition is discovered, and even for fear of contaminating someone. Under this prerogative, it was possible to identify absolute adherence to antiretroviral treatment, since all the interviewees adhered to the treatment, with regular withdrawals of the medication. This shows that the elderly seek to care for themselves continuously.

Since I discovered, seriously, I don't miss a day without taking it. (E2)

Since I discovered, effective, without ceasing. (E4)

In addition to the beneficial effects that the therapy provides, there are adverse implications that become part of the daily lives of the elderly using ARVT, as explained in the following statements:
Only the problem of anemia in the beginning, but then I continued well, that medicine made me anemic, but not anymore. Thank God. (E1)

\section{Yes, we shake and we feel very bad. (E7) \\ Yes, at night sometimes I feel a hurtburn. (E8)}

Coexistence with adverse effects caused by the use of antiretrovirals may, at some point, affect the quality of life of the elderly and disrupt adherence to treatment. In this scenario, once again, the health team is fundamental to clarify that such adverse events are transient.

Ingestion of medicines may mean, for some elderly people, the materialization of the existence of the disease in their organism. In addition, introducing medication into individual and social life may be an obstacle to adherence, which is not the case for those interviewed in this study. As the majority of those affected by the disease prefer to hide their diagnosis, inserting ARVT in their daily lives can mean a risk of being discovered.

\section{DISCUSSION}

The increase in the incidence of HIV/AIDS in the female population shows greater vulnerability in this population stratum, which may be associated with biological vulnerability, historical contexts related to oppression, subjugation in affective relations, or even by the imposition imposed by the partner ${ }^{(14)}$.

Elderly people with less education are more susceptible to HIV/AIDS, which reinforces the importance of teaching as a preventive measure in the fight against disease ${ }^{(15)}$. Thus, the low level of education in the population contingent formed by the elderly can affect the understanding of information provided by health professionals or passed through campaigns about the prevention of diseases, risks of contamination, immunizations, among others. Thus, elderly people are potentially more susceptible to HIV/AIDS contamination and complications from chronic diseases.

Lack of knowledge of the elderly about HIV/AIDS and misconception about the forms of transmission should be carefully considered by health professionals. It is necessary to develop educational strategies aimed at this segment of the population, with a view to prevention, guidance on HIV/AIDS transmission and behavior change in relation to exposure to the risk of sexually transmitted infections. This is because AIDS is a disease that affects all social segments and age groups, and the elderly population is susceptible to contamination, in the same way as other individuals.

The National Policy on the Elderly, instituted by Law $8,842 / 94$ and regulated by Decree 1,948/96, which guides the development of actions aimed at health promotion, prevention of injuries, health recovery and protection of the elderly population, in all levels of care of the Unified Health System (SUS), in order to guarantee health care ${ }^{(16)}$.

The manifestations of the elderly interviewed expressed that the sexual relationship was present in their life. However, the use of protective measures was neglected, since the form 
of contamination in its totality was through sex. The lack of concern about the possibility of postmenopausal pregnancy and men's difficulty in maintaining erection are factors that contribute to the non-adoption of HIV preventive measures. The study showed that the elderly did not receive guidelines on sexually transmitted infections (STIs), nor were they educated to use condoms, and that this may be the reason for the difficulty in adapting to use $\mathrm{e}^{(17)}$.

Regarding the feelings experienced by the elderly in relation to the fact that their diagnosis was revealed, in a study with elderly people living with HIV/AIDS, it was observed that, faced with the reality of prejudice and discrimination, secrecy regarding health status and the fact that only a few people in the family know about the serological condition, disadvantages the coping of the situation by the elderly ${ }^{(5)}$. This is because the family represents an important network of psychosocial support that when deprived of the truth ceases to collaborate in welcoming the elderly.

Excessive accountability for having acquired the virus is called impersonation. Sexual experiences without the use of condoms or exposures to risk situations may be the basis of this accountability. In such cases, the infected person usually disregards the responsibility of the other person involved in the sexual relationship and its contamination by the virus ${ }^{(18)}$.

Experiencing HIV/AIDS, regardless of age, requires the adoption of self-care practices. Self-care relates to the return of individuals to themselves, and then to return to the world. While this does not happen, man keeps himself focused on other things and situations than himself and therefore distant from himself ${ }^{(19)}$.

Self-care aims at valuing the individual's subjectivity and the nursing professional's demand the knowledge of the life context of each one in the quest for quality of life. Health education to encourage self-care aims to improve self-esteem, guide the means of coping with the disease, and help in adapting to the new way of life ${ }^{(20)}$.

Therefore, nursing consultation is an essential tool in the care of patients with HIV/AIDS, since it can allow the creation of a link between patient and nurse. It is a moment of reception, listening, dialogue, guidance on the therapeutic process and the importance of adherence to drug treatment ${ }^{(21)}$. Still, the nursing consultation becomes useful. in the sense of considering the subjectivities immersed in the new health condition of the patient to the elaboration of a health insurance that is not restricted to the technical-scientific conducts. For this, it is necessary that the professional nurse is based on knowledge and lack of preconceptions ${ }^{(21)}$.

Considering sexuality as an integral element of the life of the adult individual, regardless of age, when giving up sexual intercourse, the elderly may be compromising their quality of life, which is linked to well-being and satisfaction in various areas of their lives. The renunciation of sexual intercourse may be linked to the fact that they have been contaminated through sexual intercourse, something like punishment or involuntary response to their new condition. Once again, the importance of the health/nursing team and the counseling in order to demystify these thoughts is highlighted. After HIV/ AIDS virus contamination, there is nothing to prevent elderly people from having sex once they use condoms to prevent transmission to the partner.

The study highlights that the most common changes, reported by elderly people with HIV/AIDS, were in the financial, professional and social aspects. Isolation, deprivation of pleasurable activities and loss of self-care are explained by the embarrassment generated by being HIV-positive, by the fear of having his diagnosis discovered and fear of contaminating someone $\mathrm{e}^{(22)}$.

Any illness can cause a change in plans, projects and life perspective. Living with HIV/ AIDS causes the elderly to perceive themselves as protagonists in the construction of a future with quality of life, seeking strategies to cope with the complexity of the disease ${ }^{(23)}$.

Regarding the incorporation and acceptance of the new health condition, the elderly showed improvements in life, after a period of diagnosis, since it meant a milestone for pending problems to be solved, such as: separation of the husband, resumption of studies, the increase of self-care and leisure activities $^{(22)}$. The diagnosis in this phase of life brings changes and requires a reorganization of the identity of the elderly so that they can take care of themselves and continue living with quality of life.

A significant component that integrates self-care is adherence to treatment, since among the changes experienced by the elderly after diagnosis is the treatment, since every person diagnosed with HIV/AIDS, regardless of viral load and lymphocyte T-CD4 + count, should initiate the use of Antiretroviral Therapy (ARVT) as early as possible ${ }^{(7)}$. It is worth mentioning that the first half of ARVT is important. Improvement in clinical status, adequate immune response and viral suppression are expected results in patients adhering to drug therapy, although antiretroviral reactions and hypersensitivity may occur especially in the first three months of treatment ${ }^{(7)}$. The human being has an intrinsic connection with self-care, and can be considered the practice that assists existence in the world. The manifestations of care vary from person to person, since each one develops own ways of self-care ${ }^{(24)}$.

Adherence to treatment is a complex and multifactorial process that encompasses physical, psychological, social, cultural and behavioral aspects. Thus, aspects related to self care are present in this scenario, since adherence demands shared and shared decisions between the health service and the individual. It is important that he or she knows the purpose of the therapy and participates in the decision to initiate it. The patient should be informed of the importance of taking the medication in the dose and frequency ${ }^{(7)}$.

In this context, this study mentions that, in order to promote the adherence of the elderly to drug therapy, information on adverse effects, appropriate times for drug can be used to minimize adverse effects ${ }^{(25)}$.

\section{Limitations of the study}

The limitations in this study are related to the difficulty in approaching the elderly participants, especially, by the researched topic. In addition, the reduced number of participants constitutes a limitation, since the data presented here cannot be generalized. 


\section{Contributions to the area of nursing and public health}

Considering the verified results, it is expected that this will contribute to other researches being carried out with this theme and with new approaches. Likewise, it is understood that the data contained herein can be used by health professionals, especially nurses, to stimulate reflection on the improvements in the care provided to elderly users who have HIV/AIDS and need support for coping with their afflictions and adaptation to the changes caused by the discovery of being seropositive. Also, it is considered that this study could strengthen knowledge in the areas of gerontological nursing and nursing in communicable diseases, since there are few studies articulating these themes.

\section{CONCLUSION}

The elderly population has been growing considerably in Brazil in recent years, due in part to the increase in life expectancy. Parallel to this is the increase in the number of HIV/ AIDS cases in people aged 60 and over, characterizing changes in the disease profile.

Results show that the knowledge of the elderly about HIV/ AIDS before the contamination was superficial and distorted. However, it is possible to identify that the elderly have increased their knowledge after being diagnosed with HIV/ AIDS. This may be due to the scarcity of campaigns aimed at this population or even to the inadequate use of the language used, which hampers the understanding of this population contingent. Or, by the stereotype that the elderly person is asexual, implanted both in society and in health services, which causes this subject to be neglected by professionals, not constituting an aspect addressed and investigated in all health actions developed with the elderly user of the service.

Among the changes felt by the elderly, the changes in social and health interactions were identified, characterized by the isolation and deprivation of pleasurable activities, often related to the understanding of the value of having been contaminated. In relation to feelings, such as guilt, embarrassment and shame appear as members of the life of the elderly seropositive. The confidentiality was the situation cited by most of the interviewees, because they prefer that no one or that only someone very close to know of its diagnosis. Fear of prejudice or censorship, too, causes them to be silent.

Self-care belongs to each individual, it involves questions of self-knowledge, self-perception, and health. It is essential for the support of well-being and manifested by the elderly in this study through attitudes such as: renunciation of some habits, adoption of healthier food and, especially, adherence to antiretroviral treatment.

Therefore, it is understood that public policies and campaigns must be rethought in order to prevent and clarify HIV/ AIDS. In this sense, the nursing professional should be attentive and provide comprehensive care to the elderly, avoiding prejudices or stigmas that could affect the early diagnosis of HIV/AIDS in the elderly who access health services.

\section{REFERENCES}

1. Dourado MB, Oliveira ALB, Menezes TMO. Perception of nursing undergraduate students on self-aging. Rev Bras Enferm[Internet]. 2015[cited 2016 Oct 23];68(2):278-83. Available from: http://www.scielo.br/pdf/reben/v68n2/en_0034-7167-reben-68-02-0278.pdf .

2. Organização Mundial de Saúde. OMS. The uses of epidemiology in the study of the elderly. Geneva: WHO; 1984.

3. Ervatti LR, Borges GM, Jardim AP. (Orgs.). Mudança Demográfica no Brasil no Início do Século XXI: subsídios para as projeções da população [Internet]. Rio de Janeiro: IBGE; 2015[cited 2016 Oct 23]. Available from: http//www.biblioteca.ibge.gov.br/ visualização/livros/liv93322.pdf

4. Trench B, Rosa TEC. Nós e o outro: envelhecimento, reflexões, práticas e pesquisa. São Paulo: Instituto de Saúde, 2011. 290p.

5. Alencar RA, Ciosak SI. Late diagnosis and vulnerabilities of the elderly living with HIV/AIDS. Rev Esc Enferm USP[Internet]. 2015[cited 2016 Oct 23];49(2):229-35. Available from: http://www.scielo.br/pdf/reeusp/v49n2/0080-6234-reeusp-49-02-0229.pdf

6. Perdigão IS, Oliveira RCC, Zagnoli SBC, Neves JAC. Susceptibility o folders to human immunodeficiency virus: causes, consequences, policies and nurses interventions. Rev Enferm [Internet]. 2013[cited 2015 Nov 10];16(3):207-22. Available from: http://periodicos.pucminas.br/index.php/enfermagemrevista/article/view/12893

7. Brasil. Ministério da Saúde. Departamento de DST, AIDS e Hepatites Virais, Secretaria de Vigilância em Saúde, Ministério da Saúde. Protocolo clínico e diretrizes terapêuticas para manejo da infecção pelo HIV em adultos. Brasília: Ministério da Saúde; 2015.

8. Silva AA, Terra MG, Motta MGC, Leite MT, Padoin SMM. Nursing and self care: perception of itself as an existential body in the world. Rev Enferm UERJ [Internet]. 2013 [cited 2016 Oct 13];21(3):366-70. Available from: http://www.facenf.uerj.br/v21n3/ v21n3a15.pdf

9. Brasil. Ministério da Saúde. Conselho Nacional de Saúde. Resolução № 466 de 12 de dezembro de 2012. Aprova as diretrizes e normas regulamentadoras de pesquisas envolvendo seres humanos. Brasília, 2012.

10. Folstein MF, Folstein SE, Mchugh PR. "Mini-mental state". A practical method for grading the cognitive state of patients for the clinician. J Psychiatr Res[Internet]. 1975 [cited 2015 Jul 23];12(3):189-98. Available from: https://www.ncbi.nlm.nih.gov/ pubmed/1202204

11. Brucki SMD, Nitrini R, Caramelli P, Bertolucci PHF, Okamoto IH. Suggestions for utilization of the mini-mental state examination 
in Brazil. Arq Neuropsiquiatr[Internet]. 2003 [cited 2015 Jul 23];61(3-B):777-81. Available from: https://www.scielo.br/pdf/anp/ v61n3B/17294.pdf

12. Bardin L. Análise de conteúdo. Edições 70. São Paulo, 2011.

13. Brasil. Ministério da Saúde. Secretaria de Vigilância em Saúde. Programa Nacional de DST e Aids. Contribuição dos centros de testagem e aconselhamento para universalizar o diagnóstico e garantir a equidade no acesso aos serviços. Brasília: Ministério da Saúde, 2008.

14. Moreschi C, Siqueira DF, Freitas HMB, Schaurich D, Biazus CD, Freitas PH. Mulheres e vulnerabilidades ao HIV/AIDS. Saúde (Santa Maria). [Internet]. 2012 [cited 2016 Mar 03];38(2):859. Available from: https://periodicos.ufsm.br/revistasaude/article/ view/5145/pdf

15. Rocha FCV, Freitas Filho FC, Macêdo Junior JA, Rosa YRD. Conhecimento dos idosos sobre HIV/AIDS. Rev Interd [Internet]. 2013 [cited 2015 Nov 20];6(2):137-43. Available from: http://revistainterdisciplinar.uninovafapi.edu.br/index.php/revinter/article/view /57/pdf_31

16. Brasil. Ministério da Saúde. Lei No 8.842, de 4 de janeiro de 1994. Dispõe sobre a política nacional do idoso, cria o Conselho Nacional do Idoso e dá outras providências. Brasília, 1994.

17. Silva LVS, Minervino SS, Bueno AAB, Fassarella CS. O uso de preservativo e a prevenção de doença sexualmente transmissível na terceira idade. Rev Cuid Saúde[Internet]. 2014 [cited 2016 Oct 27];8(1):1-11. Available from: http://publicacoes.unigranrio.br/ index.php/rcs/article/view/1939/1093

18. Poletto M P, Heck C, Calsa DC, Moskovics JM. Pensamentos automáticos e crenças centrais associados ao HIV/AIDS em indivíduos soropositivos. Temas Psicol[Internet]. 2015 [cited 2016 Sep 10];23(2):243-53. Available from: http://pepsic.bvsalud.org/pdf/tp/ v23n2/v23n2a01.pdf

19. Galvão BA. A ética em Michel Foucault: do cuidado de si à estética da existência. Intuitio[Internet]. 2014 [cited 2016 Nov 05];7(1):157-68. Available from: http://revistaseletronicas.pucrs.br/ojs/index.php/intuitio/article/view/17068/11428.

20. Roso CC, Beuter M, Kruse MHL, Girardon-Perlini NMO, Jacobi CS, Cordeiro FR. Self-care of patients in conservative treatment of chronic renal insufficiency. Texto Contexto Enferm [Internet]. 2013[cited 2016 Nov 05];22(3):739-45. Available from: http://www. scielo.br/pdf/tce/v22n3/en_v22n3a21.pdf

21. Macêdo SM, Sena MCS, Miranda KCL. Consulta de enfermagem ao paciente com HIV: perspectivas e desafios sob a ótica de enfermeiros. Rev Bras Enferm[Internet]. 2013[cited 2016 Nov 05];66(2):196-201. Available from: http://www.scielo.br/pdf/reben/ v66n2/07.pdf

22. Silva LC, Felício EEAA, Casétte JB, Soares LA, Morais RA, Prado TS, et al. Impacto psicossocial do diagnóstico de HIV/Aids em idosos atendidos em um serviço público de saúde. Rev Bras Geriatr Gerontol[Internet]. 2015[cited 2015 Dec 08];18(4):821-33. Available from: http://www.scielo.br/pdf/rbgg/v18n4/pt_1809-9823-rbgg-18-04-00821.pdf

23. Costa JM. HIV/Aids na velhice: a fala dos idosos soropositivos na cidade de Recife. [Tese]. Universidade Católica de Pernambuco. Recife, 2013.

24. Michel T, Lenardt MH, Willig M H, Alvarez AM. From real to ideal: the health (un)care of long-lived elders. Rev Bras Enferm[Internet]. 2015[cited 2016 Dec 26];68(3):398-405. Available from: http://www.scielo.br/pdf/reben/v68n3/en_0034-7167reben-68-03-0398.pdf

25. Santana PPC, Andrade M, Santos El, Santo FHE, Braga ALS, Teixeira PA. Scientifc Nursing evidences about HIV/Aids among elderly: a literature review. Rev Baiana Enferm [Internet]. 2015[cited 2016 Oct 24];29(3):278-89. Available from: https://portalseer. ufba.br/index.php/enfermagem /article/download/11965/pdf_11 